\title{
RESEARCH
}

\section{Estrogen receptor $\alpha$ regulates the expression of syndecan-1 in human breast carcinoma cells}

\author{
Emmanuelle Fleurot ${ }^{1}$, Caroline Goudin ${ }^{1}$, Vincent Hanoux¹, Pierre-Jacques Bonnamy¹ and Jérôme Levallet ${ }^{1,2}$ \\ ${ }^{1}$ Normandie Univ, UNICAEN, OERECA, Caen, France \\ 2Normandie Univ, UNICAEN, CEA, CNRS, ISTCT/CERVOxy Group, Caen, France
}

Correspondence should be addressed to J Levallet: jerome.levallet@unicaen.fr

\begin{abstract}
Breast cancer $(\mathrm{BC})$ is the primary cause of cancer-related mortality among women. Patients who express the estrogen receptor (ER), which mediates the tumorigenic effects of estrogens, respond to antihormonal therapy. Loss of ER expression or acquired resistance to E2 is associated with aggressive malignant phenotypes, which lead to relapse. These BC subtypes overexpress syndecan-1 (SDC1), a transmembrane heparan sulfate proteoglycan that mediates angiogenesis as well as the proliferation and invasiveness of cancer cells. We showed here that the activation of ER-alpha (ER $\alpha)$ by estrogens induces downregulation of SDC1 expression in ER(+) MCF7 cells but not in T47D cells. Loss of ER $\alpha$ expression, induced by RNA interference or a selective ER downregulator, led to subsequent SDC1 overexpression. E2-dependent downregulation of SDC1 expression required de novo protein synthesis and was antagonized by treatment with BAY 11-7085, an irreversible inhibitor of $I_{\kappa} B \alpha$ phosphorylation, which inhibits the activation of NFKB. Downregulation of SDC1 expression required ER $\alpha$ and activation of IKK, but was independent to downstream transcriptional regulators of NFKB. BAY 11-7085 prevented E2-mediated phosphorylation of ER $\alpha$ on Ser118, increasing its proteasomal degradation, suggesting that IKK stabilized E2-activated ER $\alpha$, leading to subsequent downregulation of SDC1 expression. Our results showed that sustained ER signaling inhibits SDC1 expression. Such antagonism elucidates the inverse correlation between SDC1 and ER expression in ER(+) BC as well as the overexpression of SDC1 in hormone receptor-negative $B C$ subtypes with the most aggressive phenotypes. These results identify SDC1 as an attractive therapeutic target for BC as well as for other endocrineassociated cancers.
\end{abstract} Key Words

\section{Introduction}

Breast cancer $(\mathrm{BC})$ is a heterogeneous disease with distinct clinical outcomes which represents $25 \%$ of cancers of women worldwide (Torre et al. 2015). BC is the primary cause of cancer-related mortality among women (Torre et al. 2015) and are classified into subtypes according to the findings of histological, genetic and molecular analyses. Subtypes are defined according to the expression of estrogen (ER) or progesterone receptors (PR), with or without the expression of human erb-b2 receptor tyrosine kinase 2 (HER2) (Malhotra et al. 2010). ER(+) tumors represent approximately $70 \%$ of BCs, indicating that tumor progression is mediated by estrogens (DeSantis et al. 2011).

The ligand-activated nuclear transcription factors ER $\alpha$ and ER $\beta$ (encoded by ESR1 and ESR2, respectively) mediate 
the biological functions of estrogens, directly through binding to estrogen response elements (ERE) of target genes or through binding to transcription factors such as AP-1, SP1 or NFkB (Galien \& Garcia 1997, Saville et al. 2000, O'Lone et al. 2004). ER activity is regulated as well by posttranslational modifications such as phosphorylation, acetylation, sumoylation or ubiquitination (Le Romancer et al. 2011). Estrogen markedly influences the patterns of gene expression of $\mathrm{BC}$ cells, and the expression of ERs, their functions or both contribute to tumorigenesis and tumor progression and therefore serve as targets for therapy and diagnostic markers (DeSantis et al. 2011). Although antiestrogens are used to treat BCs, they are not effective inhibitors of the proliferation of all ER(+) tumor cells. Thus, de novo or acquired resistance leads to the relapse of approximately $20-30 \%$ of patients. The triple-negative $\mathrm{BC}$ (TNBC) is the subtype that is the most resistant to therapies that target hormones (Castrellon 2017).

Complex interactions between the mitogenic signal transduction pathways and the components of the extracellular matrix govern the development and acquisition of resistance to cancer chemotherapy. Transmembrane heparan sulfate proteoglycan syndecan-1 (SDC1) is an essential component of the cellular microenvironment, and although it lacks catalytic activity, SDC1 mediates cytoskeletal organization as well as cellular adhesion, migration, proliferation and differentiation (Bernfield \& Sanderson 1990). SDC1 may act as a coreceptor that regulates intracellular signal transduction pathways through binding the components of the extracellular matrix or growth factors (Multhaupt et al. 2009). Additionally, SDC1 translocates to the nucleus where it interacts with proteins such as transcription factors or histones to influence the expression of target genes (Brockstedt et al. 2002, Szatmári et al. 2012).

Evidence indicates that SDC1 expression is stringently regulated, and its deregulation contributes to numerous diseases, including cancer (Szatmári et al. 2015). SDC1 is overexpressed in the most aggressive subtypes of $\mathrm{BC}$ and is associated with tumor progression, angiogenesis, higher histological grade of tumors and shorter relapse-free survival (Maeda et al. 2006). Moreover, SDC1 is a marker of aggressiveness and chemoresistance of human BCs (Barbareschi et al. 2003, Götte et al. 2006). Interestingly, overexpression of SDC1 inversely correlates with ER expression (Barbareschi et al. 2003) and most ER(-) BCs, including the TNBC subtype, overexpress SDC1 (Baba et al. 2006).

SDC1 overexpression by the human granulosa tumor cell line KGN drastically affects estrogen synthesis and signaling through transcriptional inhibition of the expression of CYP191A and ESR2 (Colombe et al. 2017). Considering these data, we hypothesized that antagonism between E2-mediated signaling and SDC1 metabolism may contribute to mammary tumorigenesis. To this end, we studied the regulation of SDC1 expression in response to estrogen stimulation in both ER(+) MCF-7 and T47D cell lines and in the ER(-) MDA-MB-231 mammary carcinoma cell line.

\section{Materials and methods}

\section{Materials}

DMEM, Ham-F12 medium and antibiotics were purchased from Dominique DUTSCHER SAS (Brumath, France). Goat polyclonal (AF2780) anti-human Syndecan-1 antibody was obtained from R\&D Systems. ESR1-antibody (F10) was from Santa Cruz Biotechnology and anti-Actin (Ab-1) from Millipore. Fetal bovine serum (FBS), OptiMEM, Lipofectamine RNAiMax, ECL were purchased from Thermo-Fisher Scientific. M-MLV-RT, RNasin, GoTaq qPCR Master-Mix were from Promega. Positively charged nylon membrane (Amersham Hybon-N+, GE Healthcare, Life Sciences). E2, propyl-pyrazole-triol (PPT), diarylpropionitrile (DPN), G1, G15 and SP600,125, fluoroshield were from Sigma. Ly290,004, UO126, BAY 11-7085 (Bay) and MG-132 were purchase from Selleckchem.

\section{Cell line and culture conditions}

The human mammary adenocarcinoma cells MCF7 (ATCC HTB-22) and MDA-MB-231 (ATCC HTB-26) were obtained from the European Collection of Authenticated Cell Cultures (ECACC). T47D cells are generous gift from Dr Le Romancer (INSERM-U1052, Centre de Recherche en Cancérologie de Lyon, France). Cells were cultured in Ham's/DMEM (HD) medium (1:1/v:v) supplemented with $10 \%(\mathrm{w} / \mathrm{v})$ FBS, $2 \mathrm{mmol} / \mathrm{L}$ glutamine, antibiotics (50 IU $/ \mathrm{mL}$ penicillin, $50 \mu \mathrm{g} / \mathrm{mL}$ streptomycin, $100 \mu \mathrm{g} / \mathrm{mL}$ kanamycin) and $0.25 \mu \mathrm{g} / \mathrm{mL}$ amphotericin $\mathrm{B}$ and incubated at $37^{\circ} \mathrm{C}$ with $5 \% \mathrm{CO}_{2}$.

\section{Hormonal and chemical treatments}

Before treatments cells were cultured during 5 days in DMEM without phenol red, supplemented with $4.5 \mathrm{~g} / \mathrm{L}$ glucose and $10 \%(\mathrm{w} / \mathrm{v})$ of charcoal-treated steroid-free FBS (MEM) for steroid deprivation. Concentration of $17 \beta$-estradiol (E2) ranging from $10^{-12} \mathrm{~mol} / \mathrm{L}$ to $10^{-8} \mathrm{~mol} / \mathrm{L}$ 
was used, and $10 \mathrm{ng} / \mathrm{mL}$ TNF $\alpha$ during a time of incubation ranging from $30 \mathrm{~min}$ to $96 \mathrm{~h}$. Anti-estrogen ICI182,780 (ICI) and 4-OH-tamoxifen (Tam) were used at $10^{-8} \mathrm{~mol} / \mathrm{L}$ as well as selective estrogen agonist and antagonist (PPT, DPN, G1 and G15) or for kinase pathway inhibitors (H89, Ly290,004, UO126, SP600,125 and BAY 11-7085) a concentration of $10^{-5} \mathrm{~mol} / \mathrm{L}$. For experiments with cycloheximide (CHX; $10 \mu \mathrm{g} / \mathrm{mL}$ ), actinomycin D (ACT; $2 \mu \mathrm{mol} / \mathrm{L}$ ) cells were pre-incubated for $30 \mathrm{~min}$ and then further incubated with E2 for indicated period.

\section{Small-interfering RNA studies}

MCF-7 cells were seeded in 24-well plates in MEM without antibiotics $24 \mathrm{~h}$ before transfection. RelA-siRNA (5'-CCA-UCA-ACU-AUG-AUG-AGU-UdTdT-3'; 5'-AACUCA-UCA-UAGUUG-AUG-GdTdT-3'), ESR1-siRNA (5'-UCA-UCG-CAU-UCC-UUG-CAA-AdTdT-3'; 5'-UUU-GCAAGG-AAU-GCG-AUG-AdTdT-3') and siRNA-negative control (Medium-GC duplex\#2) were diluted in Opti-MEM medium and transfected using Lipofectamine RNAiMax. At $6 \mathrm{~h}$ after transfection, medium was renewed with medium-containing antibiotics.

\section{RNA extraction and real-time RT-PCR}

Total RNA (250 ng) was isolated using TRI-Reagent Kit and reverse transcribed during $1 \mathrm{~h} 30$ at $37^{\circ} \mathrm{C}$ with $200 \mathrm{U}$ M-MLVRT, 20U RNasin, $0.5 \mu \mathrm{g}$ oligo dT and $100 \mu \mathrm{mol} / \mathrm{L}$ dNTP following by $5 \mathrm{~min}$ at $65^{\circ} \mathrm{C}$. Semi-quantitative PCR was performed with Mx3005P real-time PCR system (Agilent Technologies) and the detection was done by the fluorescent dye SYBRGreen with GoTaq qPCR Master-Mix.
Primer sequences are listed in Table 1. GAPDH mRNA level was used as an internal control for normalizing different samples. Cycle threshold values were normalized by housekeeping gene GAPDH. The relative mRNA expression level was calculated as fold changes relative to untreated cells using the comparative threshold cycle value $\left(2^{-\Delta \Delta C T}\right)$.

\section{Western blotting}

Cell lysates were obtained after incubation of cell layer with SDS-lysis buffer $(62.5 \mathrm{mM}$ Tris-HCl pH $6.8 ; 2 \%(\mathrm{w} / \mathrm{v})$ SDS, $10 \%(\mathrm{v} / \mathrm{v})$ glycerol; $50 \mathrm{mmol} / \mathrm{L}$ DTT; $0.01 \%(\mathrm{w} / \mathrm{v})$ bromophenol blue). Total proteins were sonicated and denatured $5 \mathrm{~min}$ at $95^{\circ} \mathrm{C}$ before loading on SDS-PAGE and electro-transferred to Hybond-ECL nitrocellulose membrane or cationic Nylon membrane (Hybond-N+, GE Healthcare Life Sciences). Membranes were blocked in 5\% nonfat dry milk in TTBS at RT for $1 \mathrm{~h}$ before probing with primary antibody (1:1000 in TTBS-1\% BSA) overnight at $4^{\circ} \mathrm{C}$. Membranes were washed with TTBS and then horseradish peroxidase-conjugated secondary IgG was used for detection. The signal was visualized with an enhanced chemiluminescence reaction kit (ECL), revealed by autoradiography and quantified by densitometry using ImageJ software. For loading control, the membranes were stripped and re-probed with mouse anti-actin antibody (Ab-1).

\section{Confocal imunocytochemistry}

Cells were grown on glass coverslips in 24-well plates, fixed with $4 \%$ paraformaldehyde and permeabilized with $100 \%$ methanol. Non-specific binding sites were blocked

Table 1 Primers used for real-time PCR.

\begin{tabular}{|c|c|c|c|}
\hline Genes & ID & Primer set & Length (bp) \\
\hline GAPDH & NM_002046 & $\begin{array}{l}\text { GAAGGTGAAGGTCGGAGTC } \\
\text { GAAGATGGTGATGGGATTTC }\end{array}$ & 225 \\
\hline ESR1 & NM_000125 & $\begin{array}{l}\text { AGACATGAGAGCTGCCAACC } \\
\text { GCCAGGCATTCTAGAAGG }\end{array}$ & 299 \\
\hline ESR2 & NM_001437.2 & $\begin{array}{l}\text { GAGTCTGGTCGTGTGAAGGA } \\
\text { ACTTCTCTGTCTCCGCACAA }\end{array}$ & 218 \\
\hline GPER1 & NM_001505 & $\begin{array}{l}\text { GCAGGTCCAGCAGAGGTACA } \\
\text { GAGCTGCTCACTCTCTGGGT }\end{array}$ & 128 \\
\hline IL6 & NM_000600.4 & $\begin{array}{l}\text { TGGGAATCCAGTGTGTGAA } \\
\text { CACAGCATTCAGGTCGTAGT }\end{array}$ & 183 \\
\hline$P G R$ & NM_001202474 & $\begin{array}{l}\text { TCGAGCTCAGCGTTTCTA } \\
\text { CACCATCCCTGCAATATCT }\end{array}$ & 183 \\
\hline RELA (p65) & NM_021975.3 & $\begin{array}{l}\text { GCCATGGACGAACTGTTCCCC } \\
\text { TGGTATCTGTGCTCCTCTCG }\end{array}$ & 166 \\
\hline$S D C 1$ & NM_001006946 & $\begin{array}{l}\text { GAAACCTCGGGGGAGAATAC } \\
\text { TACAGCATGAAACCCACCAG }\end{array}$ & 188 \\
\hline
\end{tabular}


with PBS-5\% FBS before overnight incubation with primary antibody (diluted 1:50 in PBS containing 0.3\% Triton X-100 and 1\% BSA) in a humidified dark chamber. After washing, AlexaFluor-conjugated secondary antibody (1:100) was added at RT for $1 \mathrm{~h}$. Coverslips were mounted with Fluoroshield medium containing 4',6-diamidino2-phenylindole (DAPI) for DNA counterstaining and cells were observed with a confocal laser scanning unit (FluoView-FV1000, Olympus). Immunofluorescence intensities were measured using FV10-ASW-1.7 Olympus software. For each essay, three fields/coverslip were analyzed containing around 40 individualized cells/fields and repeated for three independent experiments.

\section{Statistical analysis}

Data were analyzed using the Student's $t$-test or the oneway ANOVA followed by Dunnett's (for dose or time response) or Tukey's test (GraphPad Prism5 software) when appropriate. Data were expressed as the mean \pm s.e.m. Differences were considered statistically significant at ${ }^{*} P<0.05 ;{ }^{* *} P<0.01 ;{ }^{* *} P<0.001$.

\section{Results}

\section{E2 mediates the downregulation of SDC1 expression in MCF7 cells}

MCF7 cells were treated for $24 \mathrm{~h}$ with increasing concentrations of E2 $\left(10^{-12}-10^{-8} \mathrm{~mol} / \mathrm{L}\right)$ in phenol redfree medium supplemented with $10 \%$ charcoal-stripped FBS (MEM). E2 caused dose-dependent inhibition of SDC1 mRNA levels, reaching 70\% inhibition at $10^{-10} \mathrm{~mol} / \mathrm{L}$ (Fig. 1A). Similarly, progesterone receptor (PGR) expression was upregulated in a dose-dependent manner (Fig. 1A). E2-mediated repression of SDC1 mRNA expression occurred after $12 \mathrm{~h}$, consistent with a decrease of the immunocytochemical detection of SDC1 protein after $24 \mathrm{~h}$ (Fig. 1B and C). Such longterm regulation was confirmed by Western blot analysis (Fig. 1D). Downregulation of SDC1 mRNA and SDC1 levels was detected in cells cultured in medium containing phenol red and untreated FBS (HD) (Fig. 1E and F). Upregulation of PGR expression under the same conditions confirmed the steroid-dependent inhibition of SDC1 expression.

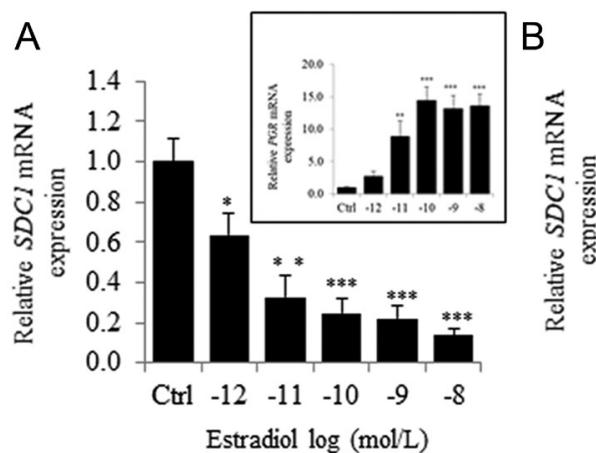

C

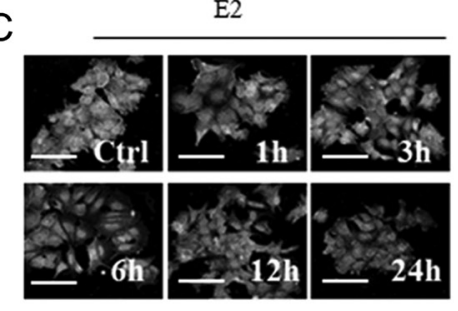

E

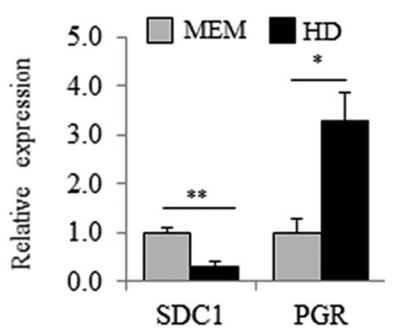

D

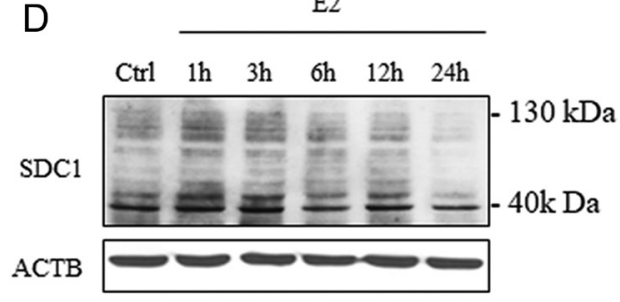

$\mathrm{F}$

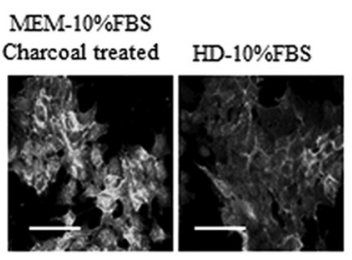

\section{Figure 1}

Estradiol induces a dose- and time-dependent inhibition of SDC1 expression in MCF7 cells. (A) Expression of $S D C 1$ (and $P G R$ in the insert panel) mRNA in MCF-7 cells cultured in estrogendeprived medium (MEM-10\% FBSdest) and treated for $24 \mathrm{~h}$ with increasing concentration of estradiol (10-12-10-8 $\mathrm{mol} / \mathrm{L})(n=4)$. (B) Expression of SDC1 mRNA measured after addition of E2 (10-8 $\mathrm{mol} / \mathrm{L})$ for increasing period of time (1-24 $\mathrm{h}$ ). (C) Immunocytochemical observation of SDC1 expression using goat polyclonal anti-SDC1 (AF2780 from R\&D) in cells treated without or with E2 (10-8 mol/L) during $24 \mathrm{~h}$. In same experimental conditions, the content of SDC1 protein was estimated by Western blot (D) (C and D are representative results from three independent experiments). (E) Expression of SDC1 and PGR measured by QRT-PCR in estrogen-deprived medium MEM or in medium containing phenol red and non-charcoal-treated FBS (HD) $(n=3)$. (F) Immunocytochemical observation of SDC1 expression after $48 \mathrm{~h}$ of cell culture in MEM or HD medium $(n=3)$ (scale bar $=50 \mu \mathrm{m})$. 
SDC1 expression by Western blot can give rise to variable results sometimes not enough demonstrative according to the protocol used (membrane used for blotting, preparation of protein extracts, antibody) but also due to the existence of glycosylated or multimeric form of protein. Furthermore, considering that the extracellular domain harbors attachment sites for heparan sulfate and chondroitin sulfate chains, molecular weight of SDC1 can ranged from $33 \mathrm{kDa}$ for SDC1 coreprotein to $130-200 \mathrm{kDa}$ with GAGs chains. Specificity of the goat polyclonal anti-human SDC1 antibody (AF2780) was confirmed using MCF7 cells overexpressing SDC1 or in MCF7 cells transfected with an SDC1-siRNA, by immunocytochemistry and Western blot (Supplementary Fig. 1, see section on supplementary data given at the end of this article). The correlation between SDC1 levels and intensity of fluorescence was further confirmed by fluorescence-activated cell sorter (FACS). Additionally, the heparinase I and III treatment of whole MCF7 cells extract reduced the molecular weight of SDC1 in Western blotting experiments onto positively charged nylon membrane and revealed with the anti-SDC1 antibody (AF2780) confirming definitely its specificity. However, after heparinase treatment the SDC1 band still appear as a smear because SDC1 also contains heterogeneous chondroitin sulfate chains which are not removed by such treatment.

All Western blot experiments have been done with nitrocellulose membrane and cationic nylon membrane (Supplementary Fig. 2). The upper band around $90 \mathrm{kDa}$ was used for quantitative analysis.

\section{Cell type-specific differential regulation of SDC1 expression by E2}

The effects of estradiol were evaluated in the ER(+), luminal subtype-A T47D cell line and in the triple-negative cell line MDA-MB-231. Although MCF7 and T47D cells expressed similar levels of SDC1 and ESR1 mRNAs (Fig. 2A), estradiol induced a slight but dose-dependent increase in SDC1 mRNA levels in T47D cells (Fig. 2B). In contrast, estradiol treatment did not affect SDC1 mRNA levels in ER(-) MDA-MB-231 cells (Fig. 2B). Consistent with the findings that T47D cells express higher level of PGR than MCF7 cells (Fig. 2A), we found that progesterone (P4) increased SDC1 mRNA expression in T47D cells but not in MCF7 cells (Fig. 2C). These data suggest that SDC1 expression was not regulated by estradiol in $\mathrm{ER}(+) / \mathrm{PR}(+)$ T47D cells. Therefore, we focused our attention on estrogen-sensitive MCF7 cells.

\section{ER $\alpha$ is required for E2-mediated downregulation of SDC1 expression in MCF7 cells}

MCF7 cells were treated with selective agonists of ER $\alpha$, ER $\beta$ and GPER (PPT, DPN and G1 at 10-8 $\mathrm{mol} / \mathrm{L}$, respectively). Only the ER $\alpha$-agonist PPT mimicked the inhibitory effects of E2 on SDC1 expression (Fig. 3A). Despite the absence of ER $\beta$ (data not shown), inhibitory effects of DPN on SDC1 expression were observed but judged as not significant, in agreement with the partial agonist effect of DPN on ER $\alpha$ (Harrington et al. 2003). We found that inhibition of SDC1 expression did not require GPER signaling. In contrast, the ER-selective antagonist tamoxifen completely blocked the E2-dependent inhibition of SDC1 mRNA and protein expression in MCF7 cells without affecting basal levels of expression (Fig. 3B and C), demonstrating that ER $\alpha$
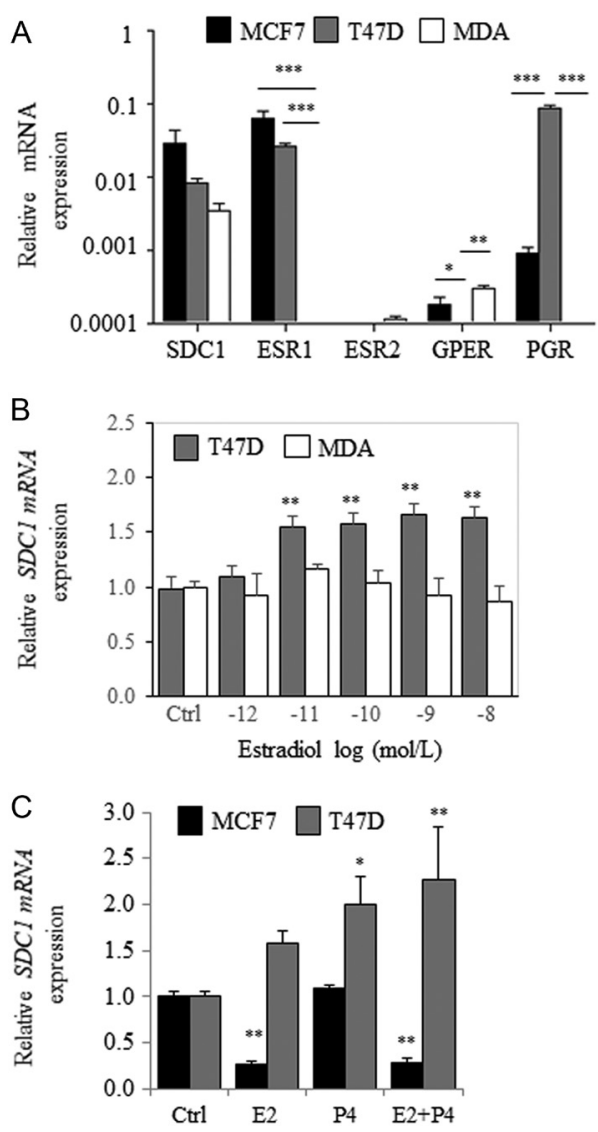

\section{Figure 2}

E2-dependent regulation of syndecan-1 expression in MCF7, T47D and MDA-MB-231 cells. (A) Relative expressions of SDC1, ESR1, ESR2, GPER and $P G R$ in MCF-7, T47D and MDA-MB-231 (MDA) cells cultured in MEM-10\% FBSdest $(n=3)$. (B) Expression of SDC1 in T47D and MDA-MB-231 cells cultured in MEM-10\% FBSdest and treated for $24 \mathrm{~h}$ with increasing concentration of estradiol (10-12-10-8 $\mathrm{mol} / \mathrm{L})$. (C) MCF7 and T47D cells were incubated for $24 \mathrm{~h}$ with E2, P4 or both (10-8 $\mathrm{mol} / \mathrm{L})$ and SDC1 mRNA level measured by QRT-PCR $(n=3)$. 
was the main mediator of the downregulation of SDC1 expression by E2.

We next investigated the effects of ER deficiency on SDC1 expression. After a 24-h treatment with the antiestrogen ICI182,780 (ICI), a significant increase in the basal level of SDC1 mRNA and a decrease in E2-induced inhibition of the levels of SDC1 mRNA were detected
(Fig. 3D). ICI treatment reversed the activation of $P G R$ expression induced by E2, confirming its efficacy (data not shown). Time-dependent degradation of ER $\alpha$ was detected after ICI treatment, which inversely correlated with SDC1 levels $\left(r^{2}=-0.926, P=0.002\right)$ (Fig. 3E). Moreover, immunocytochemical analysis detected a 30\% decrease in $\mathrm{ER} \alpha$ levels associated with a $45 \%$ increase in SDC1
A
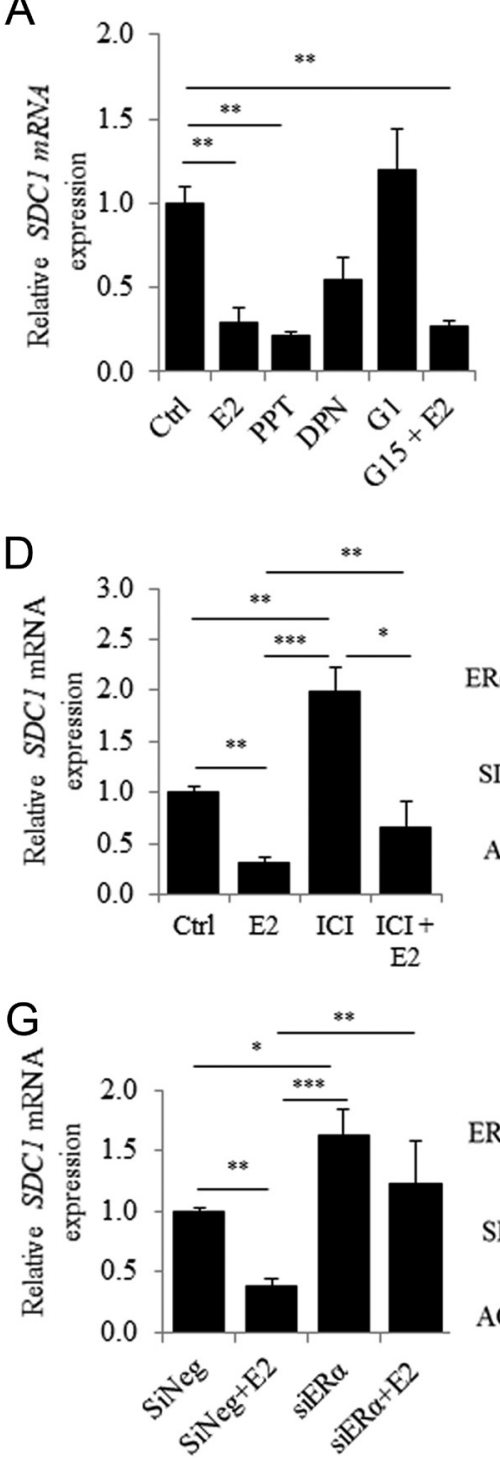

B

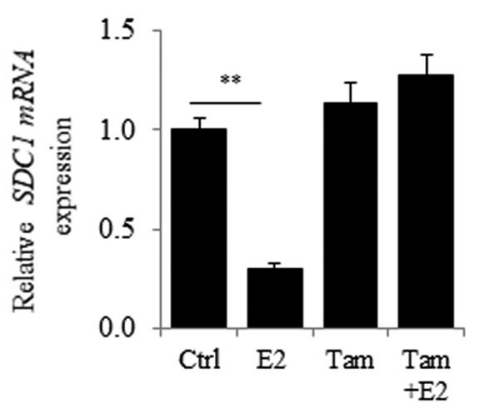

$\mathrm{E}$

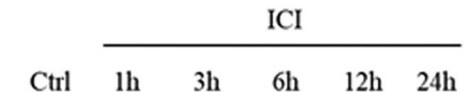

ER $\alpha 66$

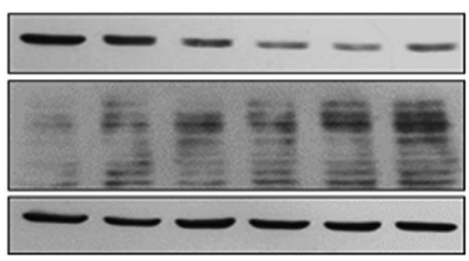

$\mathrm{H}$

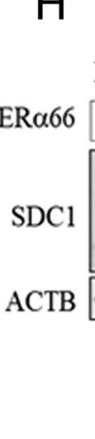

$\mathrm{F}$
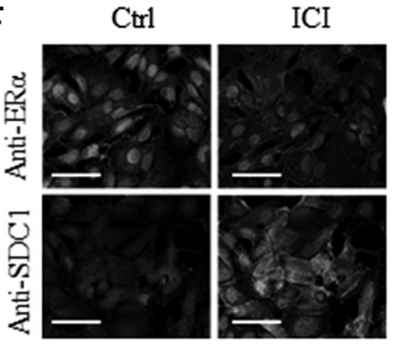

C

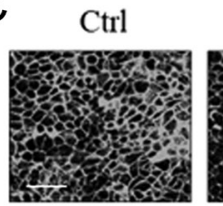

Tam
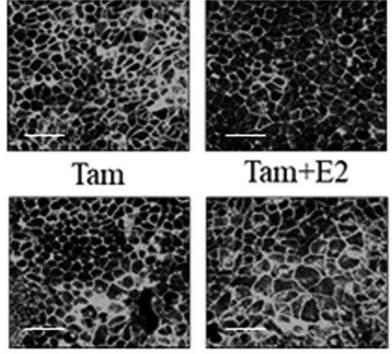

I

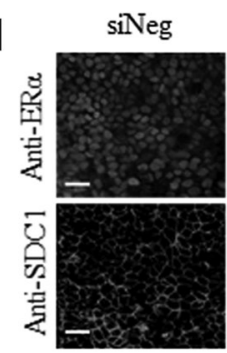

$\mathrm{Tam}+\mathrm{E} 2$

E2

$\operatorname{siER} \alpha$

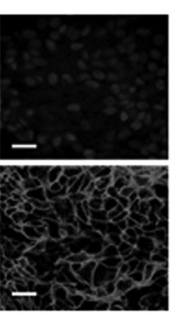

Figure 3

ER $\alpha$ mediates ligand-dependent and -independent downregulation of SDC1 expression in MCF7 cells. (A) Expression of SDC1 estimated by QRT-PCR in MCF7 cells cultured in MEM before addition of E2 (10-8 mol/L) for $24 \mathrm{~h}$ or specific agonist of ER $\alpha$ (PPT), ER $\beta$ (DPN) or GPER (G1) used at 10-8 mol/L. GPER antagonist G15 was added 30 min before E2 stimulation $(n=3)$. (B) MCF7 cells were incubated for $24 \mathrm{~h}$ with E2, tamoxifen (Tam) at $10^{-6}$ mol/L or both and SDC1 mRNA level measured by QRT-PCR $(n=3)$. (C) Immunocytochemical observation of SDC1 after $24 \mathrm{~h}$ of treatment with E2 (10-8 mol/L) and Tam $\left(10^{-6} \mathrm{~mol} / \mathrm{L}\right)($ Representative experiments from $n=3)$. (D) SDC1 mRNA expression in MCF-7 cells cultured in MEM and treated with E2, ICI (10-8 mol/L) or both for $24 \mathrm{~h}$. (E) Representative Western blot showing ER $\alpha$ and SDC1 protein expression after ICI treatment for increasing period of time. Expression levels were normalized with actin as loading control. (F) Immunocytochemical observation of SDC1 and ER $\alpha$ in MCF-7 treated for $24 \mathrm{~h}$ with or without ICI $\left(10^{-8} \mathrm{~mol} / \mathrm{L}\right)$. (G) Expression of SDC1 mRNA estimated by QRT-PCR $24 \mathrm{~h}$ after transfection of siRNA (10 nM) followed by an additional incubation $24 \mathrm{~h}$ without or with E2 $(n=3-5)$. $(\mathrm{H})$ ER $\alpha$ and SDC1 expression were estimated by Western blot $72 \mathrm{~h}$ after transfection with increasing concentration of siRNA. (I) Immunocytochemical observation of SDC1 and ER $\alpha$ in MCF7 transfected with $10 \mathrm{nM}$ of siNeg or siER $\alpha(n=3)(\mathrm{scale}$ bar $=50 \mu \mathrm{m})$. 
levels (Fig. 3F and Supplementary Fig. 3A). Similarly, silencing ESR1 expression, which completely abrogated the E2-mediated overexpression of PGR mRNA (data not shown), was associated with a significant increase in the basal level of SDC1 mRNA (63\%) (Fig. 3G) and in the levels of SDC1 (Fig. 3H, I and Supplementary Fig. 3B). These results confirm the inverse correlation between ER $\alpha$ and SDC1 levels in MCF7 cells.

\section{E2-mediated downregulation of $S D C 1$ expression requires de novo protein synthesis}

Treatment with the protein synthesis inhibitor cycloheximide (CHX) significantly reduced the E2-dependent inhibition of SDC1 expression (83.4\% untreated cells vs $44.8 \%$ CHX-treated cells) (Fig. 4A) without detectable effects on growth and cell viability
(Supplementary Fig. 4). Long-term treatment ( $24 \mathrm{~h})$ with the RNA polymerase inhibitor actinomycin D (ACT) or $\mathrm{ACT}+\mathrm{CHX}$ completely abrogated the inhibition of SDC1 expression induced by estradiol (Fig. 4A) but significantly increased cell death (Supplementary Fig. 4). During a shorter treatment with ACT, which did not detectably affect the viability of MCF7 cells, the stability of SDC1 mRNA was not significantly affected by E2 (Fig. 4B).

The potential involvement of the MAPK/ERK, PI3K/AKT or JNK signal transduction pathways on the regulation of $S D C 1$ expression was investigated. Although EGF induced rapid phosphorylation and activation of ERK1/2 and AKT (Fig. 4C), it had no effect on SDC1 expression (Fig. 4D). Further, in the presence of inhibitors of MEK, AKT and JNK (UO126, Ly294,002 or Sp600,125, respectively), inhibition of $S D C 1$ expression after estradiol treatment was not reversed.
A

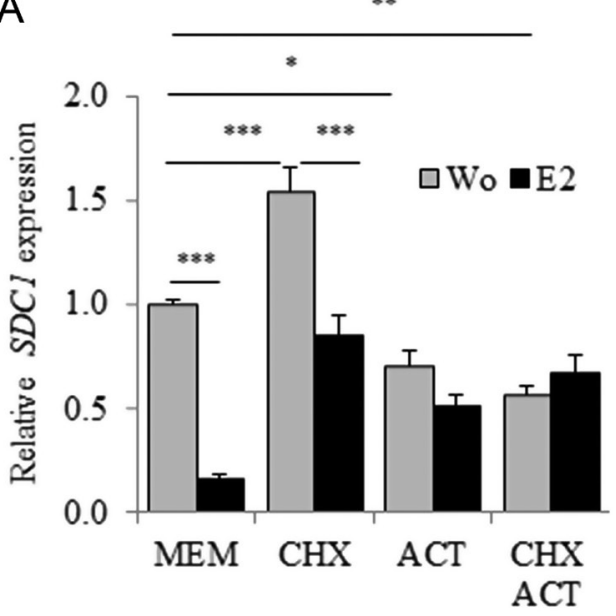

B

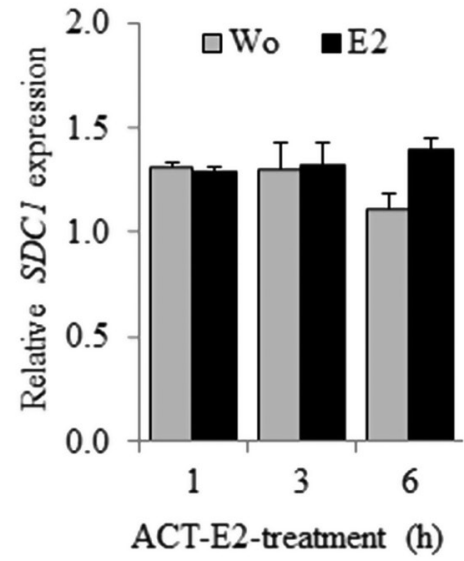

ACT-E2-treatment (h)

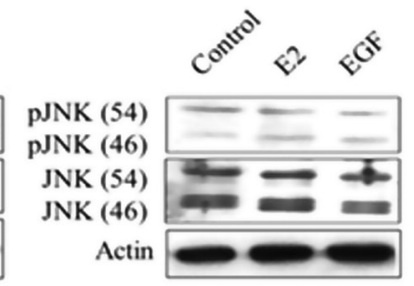

Actin
D

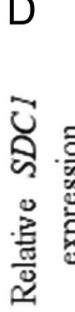

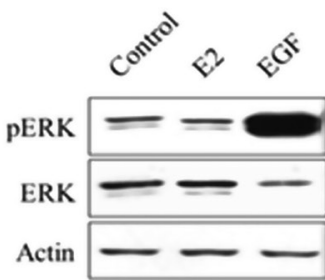

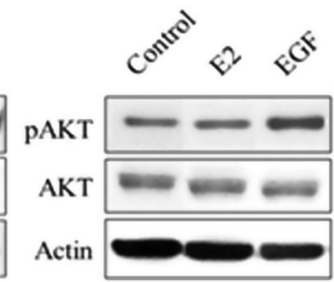

Actin

\section{Figure 4}

E2-dependent transcriptional regulation of SDC1 expression requires a de novo protein synthesis and is independent to ERK/AKT/JNK pathways. (A) Cycloheximide (CHX at $10 \mu \mathrm{g} / \mathrm{mL}$ ) and actinomycin $\mathrm{D}$ (ACT at $2 \times 10^{-6} \mathrm{~mol} / \mathrm{L}$ ) or both were first added for 30 min before subsequent E2 treatment $\left(10^{-8} \mathrm{~mol} / \mathrm{L}\right)$. Expression of SDC1 was evaluated by QRT-PCR after $24 \mathrm{~h}$ of incubation $(n=3)$. (B) Cells were treated with ACT for $30 \mathrm{~min}$ and stimulated for additional 1, 3 or $6 \mathrm{~h}$ with E2. (C) Activation/ phosphorylation of ERK, AKT and JNK pathways evaluated by Western blot 20 min after E2 (10-10 $\mathrm{mol} / \mathrm{L})$ or EGF $(10 \mathrm{ng} / \mathrm{mL})$ treatment (representative experiments). (E) MCF-7 cells were first treated with MEK, AKT and JNK inhibitors (UO126, Ly294,002 and Sp600,125, respectively) for 30 min before treatment for $24 \mathrm{~h}$ with E2 $\left(10^{-10} \mathrm{~mol} / \mathrm{L}\right)$ or EGF $(10 \mathrm{ng} / \mathrm{mL})$. SDC1 mRNA expression was quantified by QRT-PCR. Data were means \pm S.E.M. from four independent experiments $(n=4)$. $\# \# P<0.01$ compared to untreated control cells. 


\section{Inhibition of the NFKB signal transduction pathway by Bay 11-7085 (Bay) reverses ER $\alpha$-mediated downregulation of SDC1 expression}

TNFo downregulates the expression of SDC1 (Day et al. 2003). TNFa triggers the canonical $\mathrm{NFkB}$ signal transduction pathway, and the NFkB and ER-signal transduction pathways interact in BC cells (Frasor et al. 2009). Therefore, we further investigated the involvement of the NFkB signal transduction pathway in the E2-dependent downregulation of the expression of SDC1. We detected a $20 \%$ reduction (judged not statistically significant) in SDC1 mRNA expression after cells were treated with TNFo (Fig. 5A). This effect was reversed by addition of Bay, an irreversible inhibitor of IкB $\alpha$ phosphorylation, which prevents the activation of the NFkB signal transduction pathway. However, Bay treatment significantly inhibited ( $\geq$ twofold) estradiolmediated downregulation of SDC1 expression without altering the basal level of SDC1 mRNA.

Immunocytochemistry detected a significant reduction $(-42 \%, \mathrm{p}=0.035)$ of SDC1 in MCF7 cells after TNFo treatment but not with Bay (Fig. 5B). Thus, Bay partially reversed the effect of TNF $\alpha$ and completely abrogated the downregulation of SDC1 expression induced by E2. RelA is a terminal effector of the NFkB signal transduction pathway. In MCF7 cells transfected with siRelA (Fig. 5C), the basal level of SDC1 expression significantly increased, although E2-mediated inhibition was detected (Fig. 5D).
There was no significant difference in the level of SDC1 mRNA after cells were treated only with TNFo or in combination with E2 in siNeg- or siRelA-transfected cells (Fig. 5F). In MCF7 ER $\alpha$ knockouts, E2-dependent inhibition of SDC1 mRNA was not detected, and Bay treatment had no effect on SDC1 mRNA expression even in the presence of E2, suggesting that Bay-dependent effects required $\mathrm{ER} \alpha$.

We found that TNFo treatment led to a 100-fold increase in the level of IL6 mRNA, and this effect was inhibited by Bay or E2 (Supplementary Fig. 5). Further, silencing of ESR1 or RelA expression significantly reduced the E2- and TNF $\alpha$-dependent overexpression of IL6 mRNA. These data suggest that E2-dependent downregulation of SDC1 expression involves a mechanism requiring the activity of ER $\alpha$ and that activation of the IKK complex, but is independent of the downstream regulatory components of the NFkB signal transduction pathway.

\section{Bay regulates ER $\alpha$ expression and its activity through the E2-dependent phosphorylation of ERo-Ser118}

The results of the preceding experiments indicate that the IKK inhibitor Bay might alter SDC1 mRNA expression by regulating ER $\alpha$ activity through an NFkB-independent mechanism. Here, we detected similar and significant repression of ESR1 mRNA levels after treatment with Bay, E2 or Bay+E2 (Fig. 6A). However, Bay significantly reversed the E2-mediated upregulation of $P G R$,
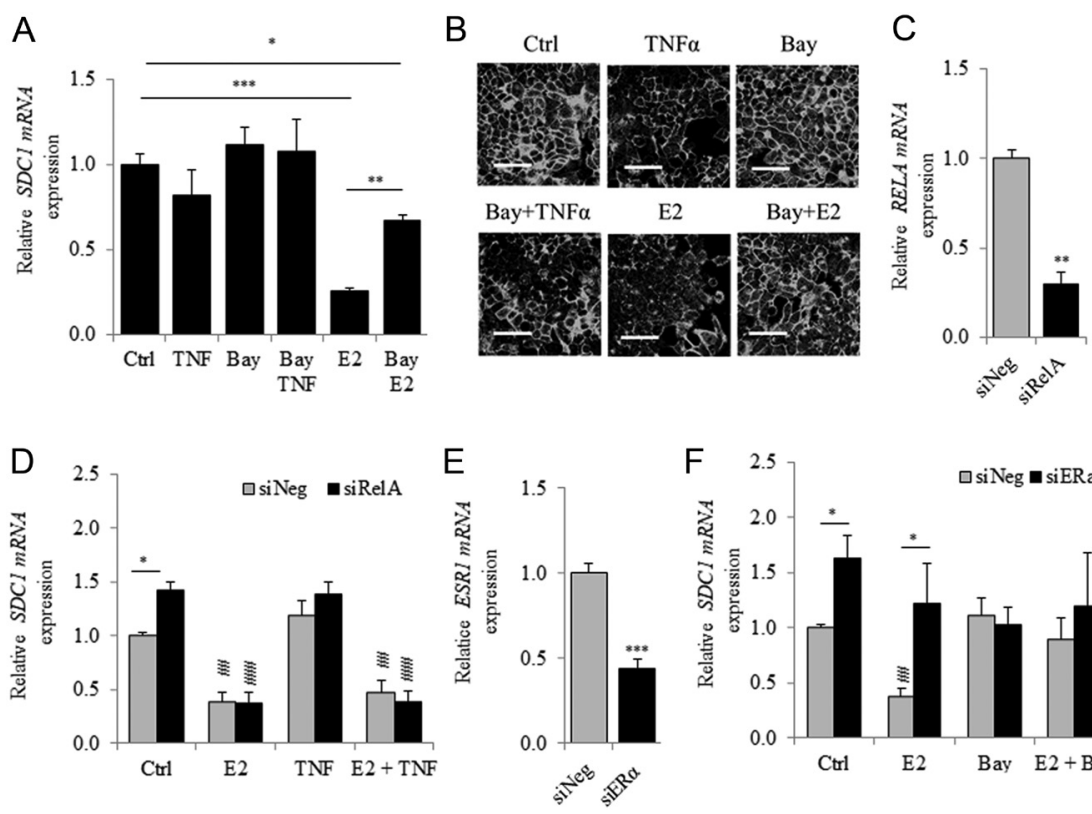

Figure 5

The inhibitor of IKK, Bay-11-7085 reduces the ER-dependent inhibition of SDC1 expression. (A) Cells were first treated for $30 \mathrm{~min}$ with the NFKB inhibitor, BAY 11-7085 (Bay) $\left(10^{-5} \mathrm{~mol} / \mathrm{L}\right)$ and E2 or TNF $\alpha(10 \mathrm{ng} / \mathrm{mL})$ was added for additional $24 \mathrm{~h}$ before SDC1 mRNA quantification by qRT-PCR. (B) Representative immunocytochemical observation of SDC1 in MCF7 after Bay pre-treatment and E2 or TNF stimulation. (Scale bar $=50 \mu \mathrm{m}$ ). (C) Expression of RELA mRNA $48 \mathrm{~h}$ after RelA-silencing $(n=3)$. (D) MCF7 was transfected with siRelA for $48 \mathrm{~h}$ and stimulated with E2, TNF $\alpha$ or both for additional $24 \mathrm{~h}$. SDC1 mRNA expression was measured by QRT-PCR $(n=3)$. (E) Expression of ESR1 mRNA $48 \mathrm{~h}$ after transfection with siESR1 $(n=3)$. (F) SDC1 mRNA expression was measured in MCF7 transfected $48 \mathrm{~h}$ with siESR1 and stimulated with E2, Bay or both for an additional period of $24 \mathrm{~h}(n=3)$. For $\mathrm{D}$ and $\mathrm{F} \# P<0.01$; $\# \# P<0.001$ compared to respective transfected control cells by one-way ANOVA with Tukey multiple comparison tests. ${ }^{*} P<0.05$ using Student's $t$-test. 
although it had no detectable effect on basal levels (Fig. 6B). The expression of ESR1 and PGR mRNAs after estrogen treatment differed in their kinetics (Fig. 6C). Thus, the E2-induced downregulation of ESR1 mRNA levels was observed after $12 \mathrm{~h}$ of treatment, consistent with the levels of SDC1 mRNA. In contrast, the upregulation of PGR mRNA was detected from $3 \mathrm{~h}$ after E2 treatment. However, the expression of these genes was affected by Bay treatment, suggesting that an IKK inhibitor affected early and late responses to E2 treatment. Thus, $6 \mathrm{~h}$ of Bay treatment were sufficient to induce a significant reduction of ER $\alpha$ levels in MCF7 cells, although E2 had no detectable effect (Fig. 6D). Moreover, treatment with MG-132, an inhibitor of the proteolytic activity of the $26 \mathrm{~S}$ proteasome complex, abrogated the effects of Bay treatment (Fig. 6E).

We next studied the phosphorylation of ER $\alpha$ on Ser118, Ser167 and Ser104/106, which affect the stability, DNA-binding activity or transcriptional activity of ER $\alpha$. Phosphorylation of ER $\alpha$ on Ser118 was very low in unstimulated MCF7 cells but was induced 15-fold by treatment with $\mathrm{E} 2$ for $30 \mathrm{~min}$ (ER $\alpha$-Ser118/ER $\alpha 66$ ratio compared with the control). However, treating cells first with Bay abrogated E2-induced phosphorylation at Ser118 without affecting the basal level of Ser118 phosphorylation (Fig. 6F). In contrast, phosphorylated ER $\alpha$-Ser167 was detectable in untreated MCF7 cells, but treatment with Bay or E2 did not induced a significant change in the ratio of phosphoER:ER. Thus, whether phosphorylation of Ser167 contributes to ER $\alpha$ activity, it was not induced by E2 treatment (Le Goff et al. 1994, present data) and may therefore not be involved in mediating the E2-dependent inhibition of SDC1 expression.

\section{Discussion}

Overexpression of SDC1 and ER(-) status serve as markers of an aggressive malignant phenotype and poor prognosis of patients with BC. However, we are unaware of convincing evidence that identifies the underlying mechanism. Therefore, we aimed here to investigate the effects of estrogens and consequences of the estrogen signaling deregulation on the expression of SDC1 in cell lines derived from human BCs.

The present study demonstrates that treatment of ER(+) MCF7 cells with E2 led to time- and dose-dependent

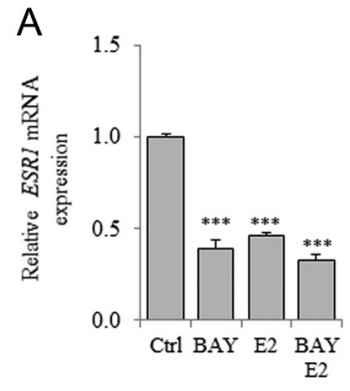

D
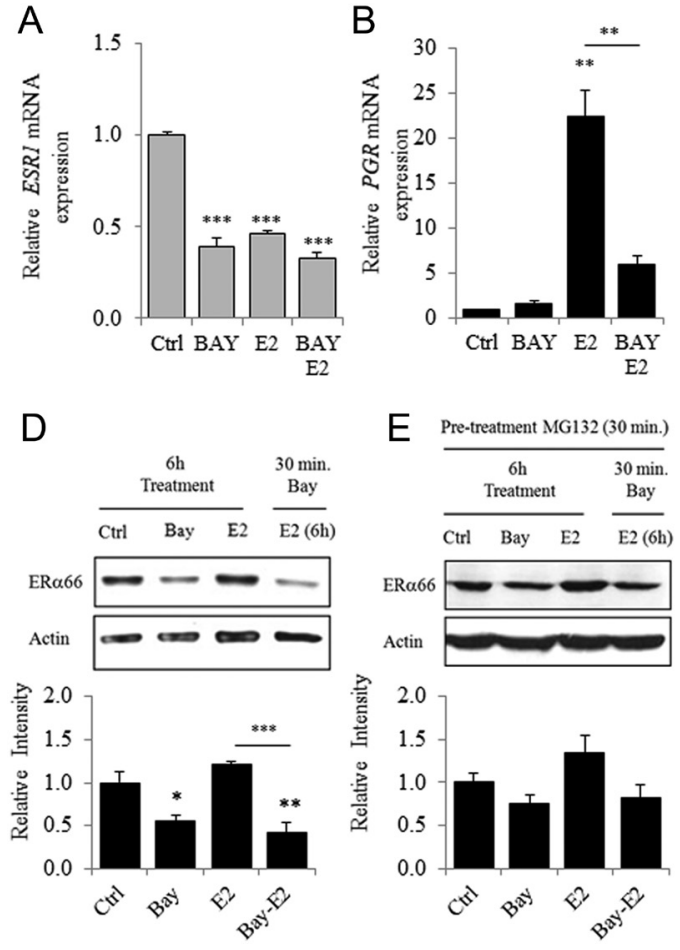

E

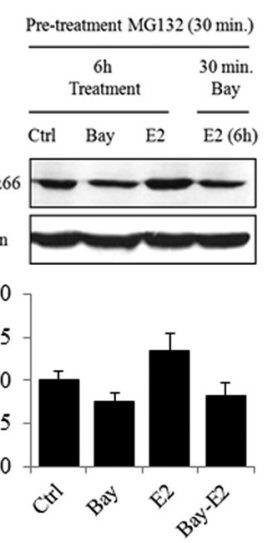

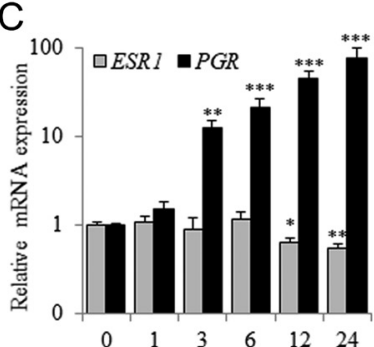

$F$

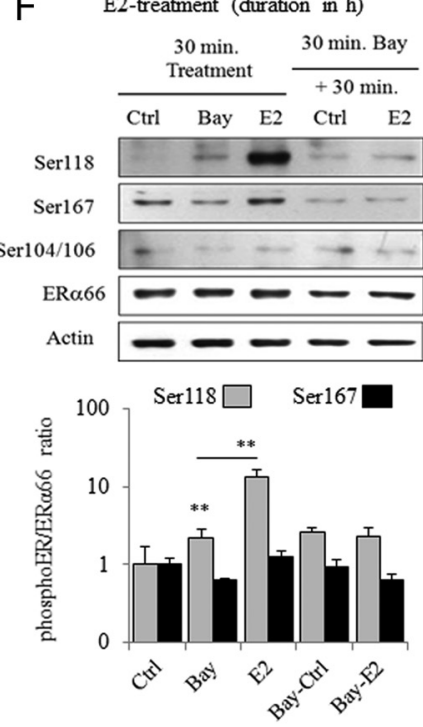

\section{Figure 6}

Bay regulates ESR1 expression and E2-dependent phosphorylation of $E R \alpha$ on Ser118. Expression of ESR1 (A), PGR (B) mRNA in MCF7 pre-treated or not with Bay (30 min) before $24 \mathrm{~h}$ of E2 treatment $(n=3)$. (C) Expression of ESR1 and PGR mRNA in MCF-7 cells treated with E2 for 1-24h of incubation. (D) ER $\alpha$ content in MCF-7 cells was determined by Western blot $6 \mathrm{~h}$ after incubation with Bay or E2 or after pre-treatment with Bay (30 min) before the E2 treatment. Upper panel is a representative experiment and lower panel a densitometric quantification of ER $\alpha /$ Actin ratio $(n=3)$. (E) Same experiments than in D were performed but with a first treatment of $30 \mathrm{~min}$ with $10 \mathrm{mM}$ of the proteasome inhibitor, MG-132. (F) Phosphorylation of ER $\alpha$ on Ser118, Ser167 and Ser104/106 observed by Western blot in MCF7 cells treated for 30 min with Bay or E2 or first treated with Bay for 30 min prior to E2 stimulation (representative experiment). Quantitative analysis of Ser118/ER $\alpha$ and Ser167/ER $\alpha$ ratio $(n=3)$. 
downregulation of the expression of SDC1 mRNA and protein. We present convincing evidence that identifies $\mathrm{ER} \alpha$ as the mediator of the effects of E2. Thus, in MCF7 cells, depletion of ER $\alpha$ was associated with the upregulation of SDC1 expression. However, we detected an opposing effect of E2 on SDC1 expression in the T47D ER(+) luminal A subtype $\mathrm{BC}$ cell line. A difference in response to $\mathrm{E} 2$ treatment between these two cell lines have been reported, expression of $50 \%$ of E2-target genes are downregulated in MCF7 cells, while most are upregulated in T47D cells (Rangel et al. 2017). Additionally, PR modulates ER $\alpha$ action directly through a physical interaction that regulates the binding of ER $\alpha$ to chromatin and the transcriptional activity of ER $\alpha$ (Mohammed et al. 2015), which may explain the differential expression of SDC1 in response to E2 treatment in $\mathrm{PR}(+)$ or $\mathrm{PR}(-) \mathrm{BC}$ cell lines. Moreover, T47D cells are more sensitive to progesterone ( $\mathrm{Yu}$ et al. 2017), leading to the downregulation of ESR1 expression in T47D cells but not in MCF7 cells (Savoldi et al. 1995).

We show here significant downregulation of SDC1 mRNA in MCF7 cells only after a 12-h treatment with $\mathrm{E} 2$ and that de novo protein synthesis was required for maximal E2-dependent transcriptional repression of SDC1 expression. Further, inhibition of the activity of RNA polymerase II had no significant effect on the half-life of SDC1 mRNA, suggesting that E2-activated ER $\alpha$ signaling downregulated the expression of SDC1 mRNA through transcriptional repression vs decreased mRNA stability. Thus E2-dependent post-transcriptional regulation of SDC1 by miRNA is unlikely, although estrogens regulate miR expression in BC cells (Klinge 2012) and the fact that SDC1 mRNA might be a potential target for some of them such as miR-10b which promotes the motility and invasiveness of BC cells (Ibrahim et al. 2012).

Numerous ERo-binding sites are present in BC cells, including MCF7 cells (Welboren et al. 2009, Ikeda et al. 2015), and some reside on the short arm of chromosome 2, which may be too far upstream of SDC1 gene (Lin et al. 2007) and are therefore unlikely to regulate SDC1 transcription. Consistently, SDC1 has never been identify as ER-binding gene in microarray experiments or chromatin immunoprecipitation (ChIP) assays (Lin et al. 2007, Hah \& Kraus 2014, Carroll 2016). Although in silico analysis does not detect putative ERE sequences in the proximal and distal promoters of $S D C 1$, transcription factors binding sites such as AP-1, SP1 and NFKB contribute to the transcriptional regulation of mouse $s d c 1$ (Hinkes et al. 1993, Vihinen et al. 1996, Iguchi-Ishiguro et al. 2012).

Estrogen signaling is induced through the interaction of ER $\alpha$ with such transcription factors (Hah \& Kraus 2014), although it is unlikely that a specific interaction between E2-activated ER $\alpha$ and a cis-acting DNA sequence located upstream of the SDC1 promoter represses transcription, because such canonical genomic signaling rapidly regulates target genes and does not require de novo synthesis. Alternatively, nongenomic actions of estrogens mediated by kinase-dependent posttranslational modification of ER may occur. However, we show here that EGF-dependent activation of ERK and AKT, or the downregulation of their expression by selective inhibitors, failed to reverse E2-mediated repression of SDC1 transcription in MCF7 cells.

In contrast, we found that BAY 11-7085, an irreversible inhibitor of NFkB activation (Pierce et al. 1997), significantly decreased E2-dependent inhibition of SDC1 expression without modifying the basal level. The $\mathrm{NF \kappa B}$ and ER signaling pathways interact (Van Laere et al. 2007, Frasor et al. 2009) and ERo can interact with NFkB by various mechanisms depending on the stimulus or cell type (Kalaitzidis \& Gilmore 2005). IKK is a complex of cytosolic factors composed of two canonical IKK factors, that is IKK $\alpha$ and IKK $\beta$, the regulatory subunit IKK $\gamma$ and a non-canonical IKKe (Verhelst et al. 2013). BAY 11-7085 prevents the activation and the phosphorylation of I $\mathrm{KB} \alpha$ by the IKK complex, leading to cytosolic sequestration of the NFkB transcription factors RelA and p50.

Activation of $\mathrm{NF \kappa B}$ pathway by $\mathrm{TNF} \alpha$ slightly influenced the expression of SDC1 in MCF7 cells, but significantly reduced the levels of SDC1 protein. Interestingly, the same differential effect between the expression of SDC1 mRNA and protein occurs in a human colorectal carcinoma epithelial cell line and human endothelial cells treated with TNFo (Kainulainen et al. 1996, Day et al. 2003). Here we show that E2-dependent downregulation of $S D C 1$ expression can be reversed by Bay and that TNF $\alpha$ treatment and silencing RelA expression had no detectable effect. In contrast, TNF $\alpha$ significantly increased the level of IL6 expression, and treatment with Bay or E2, as well as silencing the expression of ER $\alpha$ or RelA, attenuated or completely abrogated this activation. Thus, the mechanism of E2-mediated inhibition of IL6 expression involves tethering ER $\alpha$ to NFkB to prevent their binding to the IL6 promoter (Galien \& Garcia 1997), which may differ from the mechanism of E2-induced repression of SDC1 expression. Our present results show that in accordance with the presence of an NFkB-responsive elements in the proximal promoter of SDC1 (IguchiIshiguro et al. 2012), NFKB regulated the expression SDC1. However, E2-dependent repression of SDC1 expression requires an activated IKK complex and therefore is likely https://erc bioscientifica.com

https://doi.org/10.1530/ERC-18-0285
C) 2019 Society for Endocrinology Published by Bioscientifica Ltd. Printed in Great Britain 
independent of upstream or downstream components of the NFkB signal transduction pathway.

Interestingly, a shorter treatment with the IKK inhibitor led to a decrease in ER $\alpha$ levels, which was reversed by first treating cells with an inhibitor of the $26 \mathrm{~S}$ proteasome complex. Further, Bay pre-treatment prevented E2-induced phosphorylation of ER $\alpha$ on Ser118 without changing the level of ER $\alpha 66$. The phosphorylation of ER $\alpha$-Ser118 facilitates the direct binding of ER $\alpha$ to target genes by promoting the interactions of $E R \alpha$ with its coregulators and the nuclear localization of ER $\alpha$ (Marsaud et al. 2003, Le Romancer et al. 2011, Tian et al. 2015).

The activity of the $26 \mathrm{~S}$ proteasome controls the level of ER $\alpha$, and the reduction of phosphorylation of ER $\alpha$-Ser118 phosphorylation correlates with faster elimination of E2-induced ER and inhibition of ER $\alpha$ mediated gene regulation (La Rosa et al. 2012). Estrogeninduced phosphorylation of ER $\alpha$ and its transcriptional activation through phosphorylation of ER $\alpha$ on Ser118 preferentially involves ІкB kinase- $\alpha$ (IKK- $\alpha)$ (Park et al. 2005, Weitsman et al. 2006). However, IKK $\beta$ and IKKe regulate as well, ER $\alpha$ activity and the expression of its target genes (Guo et al. 2016, El-Shennawy et al. 2018). Interestingly, decreased phosphorylation of IкB $\alpha$ occurs after estrogen treatment of HeLa cells stably transfected with a cDNA encoding the human ER $\alpha$ (Sun et al. 1998) or in rat brain (Wen et al. 2004), suggesting that E2 directly regulates IKK activity. Moreover, Bay had no effect on the basal levels of ER $\alpha$ phosphorylation and the expression of SDC1. Therefore, we believe it is reasonable to conclude that in MCF7 cells, the regulation of IKK activity and subsequent phosphorylation of ER $\alpha$-Ser118, confers upon E2 the ability to regulate the stability of ER $\alpha$ as well as its transcriptional activity, and therefore, the expression of transcriptional co-regulator(s) that subsequently downregulate $S D C 1$ expression.

Estrogen can signal through IKK-dependent phosphorylation of histones bound in the vicinities of the promoters of target genes in MCF7 cells (Perillo et al. 2014). Thus, delayed downregulation mediated by ER $\alpha$ may occur through the upregulation or de novo synthesis of nuclear corepressors or associated HDACs that subsequently deacetylate chromatin to prevent recruitment of RNAPII and the transcriptional machinery to secondary ER $\alpha$ target genes (Carroll 2016, Stossi et al. 2009). Interestingly, a specific HDAC inhibitor, trichostatin A (TSA), strongly decreases ESR1 and SDC1 expression in MCF7 cells (unpublished data). Although ER $\alpha$ expression is downregulated in a TSAdependent manner in MCF7 cells (Margueron et al. 2004),
HDAC-mediated downregulation of SDC1 expression has not been shown, to our knowledge. However, HDACs may contribute to the activity of transcriptional corepressors that regulate the expression of ER-driven genes in MCF7 (Vanneste et al. 2017). This hypothesis is consistent with the paradigm that upregulation of gene expression occurs during acute exposure to estrogens, while most genes transcriptionally downregulated by E2 require sustained estrogenic treatment and their expression may be regulated through indirect mechanisms (Frasor et al. 2003).

Consistent with its structure and function as a coreceptor for growth factors and cytokines, SDC1 modulates numerous biological processes in BC cells that influence tumor progression, such as cell proliferation, adhesion, migration and angiogenesis (Nikolova et al. 2009). Accordingly, high levels of SDC1 are associated with negative prognostic parameters, shorter overall survival and resistance to chemotherapy (Baba et al. 2006, Götte et al. 2006) as well as with the loss of ER expression that occurs in most aggressive, hormone receptor-negative subtypes of BC (Barbareschi et al. 2003). Interestingly, inflammatory BC (IBC) is associated with the loss of ER expression and activation of $\mathrm{NF \kappa B}$ pathway (Van Laere et al. 2007). SDC1 can act as a coreceptor for IL6 via its glycosaminoglycan chains and promotes the activation of the inflammatory NFkB pathway (Ibrahim et al. 2013, 2017) as well as the generation of more aggressive and inflammatory BC (IBC) (Hassan et al. 2013).

The malignant progression of $\mathrm{BC}$ coincides with a shift from estrogen dependence to independence, which is associated with increases in SDC1 expression (Baba et al. 2006). Interestingly, the SDC1-binding protein (SDCBP) expression is inversely correlated with ER $\alpha$ expression, and through the activation of focal adhesion kinase, SDCBP enhances the ability of SDC1 to induce the migration and invasiveness of BC cells (Qian et al. 2013). The resistance of SDC1-deficient mice to Wnt-induced breast tumorigenesis (Alexander et al. 2000) confirms that SDC1 metabolism may be involved in the progression of $\mathrm{BC}$ and that its overexpression is a hallmark of an aggressive malignant phenotype.

In summary, we demonstrate here that ERo downregulates SDC1 expression in MCF7 cells. Estradiol, through a mechanism requiring an activated IKK complex, although independent to NFkB, increased the downregulation of SDC1 by ER $\alpha$. Inhibition of IKK by BAY-11-7085 prevented the E2-induced phosphorylation of $E R \alpha-S e r 118$, leading to its subsequent proteasomal degradation. These findings suggest that IKK increased 
the stability and activity of $\mathrm{ER} \alpha$, thereby contributing to the de novo synthesis of repressor(s) involved in the transcriptional regulation of SDC1. Although additional experiments are required to fully identify the mechanism of ER $\alpha$-dependent inhibition of SDC1 expression, our results indicate the existence of an antagonism between ER $\alpha$ signaling and SDC1 expression, thereby contributing to new insights into the mechanism responsible for the inverse correlation between SDC1 expression and ER signaling in $\mathrm{ER}(+) \mathrm{BC}$ as well as the overexpression SDC1 in the triple-negative subtype. Novel therapeutic strategies are required to treat drug-resistant ER (+) and ER (-) BCs. Our present findings strongly suggest that SDC1 may serve as a potential novel target for designing effective therapeutic strategies.

\section{Supplementary data}

This is linked to the online version of the paper at https://doi.org/10.1530/ ERC-18-0285.

\section{Declaration of interest}

The authors declare that there is no conflict of interest that could be perceived as prejudicing the impartiality of the reported research.

\section{Funding}

This work was supported by the French Ministère de l'Enseignement Supérieur, de la Recherche et de l'Innovation.

\section{Acknowledgements}

The authors thank $\mathrm{Dr} M$ Le Romancer (Centre de Recherche en Cancérologie de Lyon, France) for generously providing T47D cells, D Goux and N Elie from the Centre de Microspcopie Appliquée à la Biologie (CMABIO3), University of Caen Normandie. They also thank I Guénon from OeReCa laboratory and M Guillamin from the Service Cytométrie of the Centre François Baclesse (BioTICLA).

\section{References}

Alexander CM, Reichsman F, Hinkes MT, Lincecum J, Becker KA, Cumberledge S \& Bernfield M 2000 Syndecan-1 is required for Wnt1-induced mammary tumorigenesis in mice. Nature Genetics $\mathbf{2 5}$ 329-332. (https://doi.org/10.1038/77108)

Baba F, Swartz K, van Buren R, Eickhoff J, Zhang Y, Wolberg W \& Friedl A 2006 Syndecan-1 and syndecan-4 are overexpressed in an estrogen receptor-negative, highly proliferative breast carcinoma subtype. Breast Cancer Research and Treatment 98 91-98. (https://doi. org/10.1007/s10549-005-9135-2)

Barbareschi M, Maisonneuve P, Aldovini D, Cangi MG, Pecciarini L, Angelo Mauri F, Veronese S, Caffo O, Lucenti A, Palma PD, et al. 2003 High syndecan-1 expression in breast carcinoma is related to an aggressive phenotype and to poorer prognosis. Cancer $\mathbf{9 8}$ 474-483. (https://doi.org/10.1002/cncr.11515)
Bernfield M \& Sanderson RD 1990 Syndecan, a developmentally regulated cell surface proteoglycan that binds extracellular matrix and growth factors. Philosophical Transactions of the Royal Society of London: Series B, Biological Sciences 327 171-186. (https://doi. org/10.1098/rstb.1990.0052)

Brockstedt U, Dobra K, Nurminen M \& Hjerpe A 2002 Immunoreactivity to cell surface syndecans in cytoplasm and nucleus: tubulindependent rearrangements. Experimental Cell Research 274 235-245. (https://doi.org/10.1006/excr.2002.5477)

Carroll JS 2016 Mechanisms of oestrogen receptor (ER) gene regulation in breast cancer. European Journal of Endocrinology 175 R41-R49. (https://doi.org/10.1530/EJE-16-0124)

Castrellon AB 2017 Novel strategies to improve the endocrine therapy of breast cancer. Oncology Reviews 11 323. (https://doi.org/10.4081/ oncol.2017.323)

Colombe S, Houllier L, Fleurot E, Levallet G, Benhaïm A, Bonnamy PJ \& Levallet J 2017 Syndecan 1 represses cell growth and FSH responsiveness in human granulosa cells. Reproduction 153 797-808. (https://doi.org/10.1530/REP-17-0074)

Day RM, Mitchell TJ, Knight SC \& Forbes A 2003 Regulation of epithelial syndecan-1 expression by inflammatory cytokines. Cytokine 21 224-233. (https://doi.org/10.1016/S10434666(03)00091-7)

DeSantis C, Siegel R, Bandi P \& Jemal A 2011 Breast cancer statistics, 2011. CA: A Cancer Journal for Clinicians 61 409-418. (https://doi. org/10.3322/caac.20134)

El-Shennawy L, Dubrovskyi O, Kastrati I, Danes JM, Zhang Y, Whiteley HE, Creighton CJ \& Frasor J 2018 Coactivation of estrogen receptor and IKK $\beta$ induces a dormant metastatic phenotype in ER-positive breast cancer. Cancer Research 78 974-984. (https://doi. org/10.1158/0008-5472.CAN-17-1686)

Frasor J, Danes JM, Komm B, Chang KCN, Lyttle CR \& Katzenellenbogen BS 2003 Profiling of estrogen up- and downregulated gene expression in human breast cancer cells: insights into gene networks and pathways underlying estrogenic control of proliferation and cell phenotype. Endocrinology $1444562-4574$. (https://doi.org/10.1210/en.2003-0567)

Frasor J, Weaver A, Pradhan M, Dai Y, Miller LD, Lin CY \& Stanculescu A 2009 Positive cross-talk between estrogen receptor and NF-кB in breast cancer. Cancer Research 69 8918-8925. (https://doi. org/10.1158/0008-5472.CAN-09-2608)

Galien R \& Garcia T 1997 Estrogen receptor impairs interleukin-6 expression by preventing protein binding on the NF-кB site. Nucleic Acids Research 25 2424-2429. (https://doi.org/10.1093/ nar/25.12.2424)

Götte M, Kersting C, Ruggiero M, Tio J, Tulusan AH, Kiesel L \& Wülfing P 2006 Predictive value of syndecan-1 expression for the response to neoadjuvant chemotherapy of primary breast cancer. Anticancer Research 26 621-627.

Guo JP, Shu SK, Esposito NN, Coppola D, Koomen JM \& Cheng JQ 2016 IKKe phosphorylation of estrogen receptor $\alpha$ Ser-167 and contribution to tamoxifen resistance in breast cancer. Journal of Biological Chemistry 291 22857. (https://doi.org/10.1074/jbc. A109.078212)

Hah N \& Kraus WL 2014 Hormone-regulated transcriptomes: lessons learned from estrogen signaling pathways in breast cancer cells. Molecular and Cellular Endocrinology 382 652-664. (https://doi. org/10.1016/j.mce.2013.06.021)

Harrington WR, Sheng S, Barnett DH, Petz LN, Katzenellenbogen JA \& Katzenellenbogen BS 2003 Activities of estrogen receptor alpha- and beta-selective ligands at diverse estrogen responsive gene sites mediating transactivation or transrepression. Molecular and Cellular Endocrinology 206 13-22. (https://doi.org/10.1016/S03037207(03)00255-7)

Hassan H, Greve B, Pavao MSG, Kiesel L, Ibrahim SA \& Götte M 2013 Syndecan-1 modulates $\beta$-integrin-dependent and interleukin-6- 
dependent functions in breast cancer cell adhesion, migration, and resistance to irradiation. FEBS Journal 280 2216-2227. (https://doi. org/10.1111/febs.12111)

Hinkes MT, Goldberger OA, Neumann PE, Kokenyesi R \& Bernfield M 1993 Organization and promoter activity of the mouse syndecan-1 gene. Journal of Biological Chemistry 268 11440-11448.

Ibrahim SA, Yip GW, Stock C, Pan J-W, Neubauer C, Poeter M, Pupjalis D, Koo CY, Kelsch R, Schüle R, et al. 2012 Targeting of syndecan-1 by microRNA miR-10b promotes breast cancer cell motility and invasiveness via a Rho-GTPase- and E-cadherindependent mechanism. International Journal of Cancer $\mathbf{1 3 1}$ E884-E896. (https://doi.org/10.1002/ijc.27629)

Ibrahim SA, Hassan H, Vilardo L, Kumar SK, Kumar AV, Kelsch R, Schneider C, Kiesel L, Eich HT, Zucchi I, et al. 2013 Syndecan-1 (CD138) modulates triple-negative breast cancer stem cell properties via regulation of LRP-6 and IL-6-mediated STAT3 signaling. PLoS ONE 8 e85737. (https://doi.org/10.1371/journal.pone.0085737)

Ibrahim SA, Gadalla R, El-Ghonaimy EA, Samir O, Mohamed HT, Hassan H, Greve B, El-Shinawi M, Mohamed MM \& Götte M 2017 Syndecan-1 is a novel molecular marker for triple negative inflammatory breast cancer and modulates the cancer stem cell phenotype via the IL-6/STAT3, Notch and EGFR signaling pathways. Molecular Cancer 16 57. (https://doi.org/10.1186/s12943-017-0621-z)

Iguchi-Ishiguro H, Ouchi Y, Watanabe S \& Numabe Y 2012 Analysis of syndecan-1 gene promoter during mouse tooth development. Archives of Oral Biology 57 531-538. (https://doi.org/10.1016/j. archoralbio.2011.10.017)

Ikeda K, Horie-Inoue K \& Inoue S 2015 Identification of estrogenresponsive genes based on the DNA binding properties of estrogen receptors using high-throughput sequencing technology. Acta Pharmacologica Sinica 36 24-31. (https://doi.org/10.1038/ aps.2014.123)

Kainulainen V, Nelimarkka L, Järveläinen H, Laato M, Jalkanen M \& Elenius K 1996 Suppression of syndecan-1 expression in endothelial cells by tumor necrosis factor-alpha. Journal of Biological Chemistry 271 18759-18766. (https://doi.org/10.1074/jbc.271.31.18759)

Kalaitzidis D \& Gilmore TD 2005 Transcription factor cross-talk: the estrogen receptor and NF-Kb. Trends in Endocrinology and Metabolism 16 46-52. (https://doi.org/10.1016/j.tem.2005.01.004)

Klinge CM 2012 miRNAs and estrogen action. Trends in Endocrinology and Metabolism 23 223-233. (https://doi.org/10.1016/j. tem.2012.03.002)

La Rosa P, Pesiri V, Leclercq G, Marino M \& Acconcia F 2012 Palmitoylation regulates $17 \beta$-estradiol-induced estrogen receptor- $\alpha$ degradation and transcriptional activity. Molecular Endocrinology 26 762-774. (https://doi.org/10.1210/me.2011-1208)

Le Goff P, Montano MM, Schodin DJ \& Katzenellenbogen BS 1994 Phosphorylation of the human estrogen receptor. Identification of hormone-regulated sites and examination of their influence on transcriptional activity. Journal of Biological Chemistry 269 $4458-4466$.

Le Romancer M, Poulard C, Cohen P, Sentis S, Renoir JM \& Corbo L 2011 Cracking the estrogen receptor's posttranslational code in breast tumors. Endocrine Reviews 32 597-622. (https://doi. org/10.1210/er.2010-0016)

Lin CY, Vega VB, Thomsen JS, Zhang T, Kong SL, Xie M, Chiu KP, Lipovich L, Barnett DH, Stossi F, et al. 2007 Whole-genome cartography of estrogen receptor alpha binding sites. PLoS Genetics 3 e87. (https://doi.org/10.1371/journal.pgen.0030087)

Maeda T, Desouky J \& Friedl A 2006 Syndecan-1 expression by stromal fibroblasts promotes breast carcinoma growth in vivo and stimulates tumor angiogenesis. Oncogene 25 1408-1412. (https://doi. org/10.1038/sj.onc.1209168)

Malhotra GK, Zhao X, Band H \& Band V 2010 Histological, molecular and functional subtypes of breast cancers. Cancer Biology and Therapy 10 955-960. (https://doi.org/10.4161/cbt.10.10.13879)
Margueron R, Duong V, Castet A \& Cavaillès V 2004 Histone deacetylase inhibition and estrogen signalling in human breast cancer cells. Biochemical Pharmacology 68 1239-1246. (https://doi.org/10.1016/j. bcp.2004.04.031)

Marsaud V, Gougelet A, Maillard S \& Renoir JM 2003 Various phosphorylation pathways, depending on agonist and antagonist binding to endogenous estrogen receptor alpha (ERalpha), differentially affect ERalpha extractability, proteasome-mediated stability, and transcriptional activity in human breast cancer cells. Molecular Endocrinology 17 2013-2027. (https://doi.org/10.1210/ me.2002-0269)

Mohammed H, Russell IA, Stark R, Rueda OM, Hickey TE, Tarulli GA, Serandour AA, Birrell SN, Bruna A, Saadi A, et al. 2015 Progesterone receptor modulates ER $\alpha$ action in breast cancer. Nature 523 313-317. (https://doi.org/10.1038/nature14583)

Multhaupt HA, Yoneda A, Whiteford JR, Oh ES, Lee W \& Couchman JR 2009 Syndecan signaling: when, where and why? Journal of Physiology and Pharmacology 60 31-38.

Nikolova V, Koo CY, Ibrahim SA, Wang Z, Spillmann D, Dreier R, Kelsch R, Fischgräbe J, Smollich M, Rossi LH, et al. 2009 Differential roles for membrane-bound and soluble syndecan-1 (CD138) in breast cancer progression. Carcinogenesis 30 397-407. (https://doi. org/10.1093/carcin/bgp001)

O'Lone R, Frith MC, Karlsson EK \& Hansen U 2004 Genomic targets of nuclear estrogen receptors. Molecular Endocrinology 18 1859-1875. (https://doi.org/10.1210/me.2003-0044)

Park KJ, Krishnan V, O'Malley BW, Yamamoto Y \& Gaynor RB 2005 Formation of an IKKalpha-dependent transcription complex is required for estrogen receptor-mediated gene activation. Molecular Cell 18 71-82. (https://doi.org/10.1016/j.molcel.2005.03.006)

Perillo B, Di Santi A, Cernera G, Ombra MN, Castoria G \& Migliaccio A 2014 Nuclear receptor-induced transcription is driven by spatially and timely restricted waves of ROS. The role of Akt, IKK $\alpha$, and DNA damage repair enzymes. Nucleus 5 482-491. (https://doi.org/10.4161/ nucl.36274)

Pierce JW, Schoenleber R, Jesmok G, Best J, Moore SA, Collins T \& Gerritsen ME 1997 Novel inhibitors of cytokine-induced IkappaBalpha phosphorylation and endothelial cell adhesion molecule expression show anti-inflammatory effects in vivo. Journal of Biological Chemistry 272 21096-21103. (https://doi.org/10.1074/ jbc.272.34.21096)

Qian XL, Li YQ, Yu B, Gu F, Liu FF, Li WD, Zhang XM \& Fu L 2013 Syndecan binding protein (SDCBP) is overexpressed in estrogen receptor negative breast cancers, and is a potential promoter for tumor proliferation. PLoS ONE 8 e60046. (https://doi.org/10.1371/ journal.pone.0060046)

Rangel N, Villegas VE \& Rondón-Lagos M 2017 Profiling of gene expression regulated by $17 \beta$-estradiol and tamoxifen in estrogen receptor-positive and estrogen receptor-negative human breast cancer cell lines. Breast Cancer 9 537-550. (https://doi.org/10.2147/ BCTT.S146247)

Saville B, Wormke M, Wang F, Nguyen T, Enmark E, Kuiper G, Gustafsson JA \& Safe S 2000 Ligand-, cell-, and estrogen receptor subtype $(\alpha / \beta)$-dependent activation at GC-rich (Sp1) promoter elements. Journal of Biological Chemistry 275 5379-5387. (https://doi. org $/ 10.1074 / j b c .275 .8 .5379)$

Savoldi G, Ferrari F, Ruggeri G, Sobek L, Albertini A \& Di Lorenzo D 1995 Progesterone agonists and antagonists induce down- and up-regulation of estrogen receptors and estrogen inducible genes in human breast cancer cell lines. International Journal of Biological Markers 10 47-54. (https://doi. org/10.1177/172460089501000109)

Stossi F, Madak-Erdogan Z \& Katzenellenbogen BS 2009 Estrogen receptor alpha represses transcription of early target genes via $\mathrm{p} 300$ and CtBP1. Molecular and Cellular Biology 29 1749-1759. (https://doi. org/10.1128/MCB.01476-08) 
Sun WH, Keller ET, Stebler BS \& Ershler WB 1998 Estrogen inhibits phorbol ester-induced I kappa B alpha transcription and protein degradation. Biochemical and Biophysical Research Communications 244 691-695. (https://doi.org/10.1006/bbrc.1998.8324)

Szatmári T, Mundt F, Heidari-Hamedani G, Zong F, Ferolla E, Alexeyenko A, Hjerpe A \& Dobra K 2012 Novel genes and pathways modulated by syndecan-1: implications for the proliferation and cell-cycle regulation of malignant mesothelioma cells. PLOS ONE 7 e48091. (https://doi.org/10.1371/journal.pone.0048091)

Szatmári T, Ötvös R, Hjerpe A \& Dobra K 2015 Syndecan-1 in cancer: implications for cell signaling, differentiation, and prognostication. Disease Markers 2015 796052. (https://doi.org/10.1155/2015/796052)

Tian D, Solodin NM, Rajbhandari P, Bjorklund K, Alarid ET \& Kreeger PK 2015 A kinetic model identifies phosphorylated estrogen receptor- $\alpha$ $(\mathrm{ER} \alpha)$ as a critical regulator of $\mathrm{ER} \alpha$ dynamics in breast cancer. FASEB Journal 29 2022-2031. (https://doi.org/10.1096/fj.14-265637)

Torre LA, Bray F, Siegel RL, Ferlay J, Lortet-Tieulent J \& Jemal A 2015 Global cancer statistics, 2012. CA: A Cancer Journal for Clinicians 65 87-108. (https://doi.org/10.3322/caac.21262)

Van Laere SJ, Van der Auwera I, Van den Eynden GG, van Dam P, Van Marck EA, Vermeulen PB \& Dirix LY 2007 NF-kB activation in inflammatory breast cancer is associated with oestrogen receptor downregulation, secondary to EGFR and/or ErbB2 overexpression and MAPK hyperactivation. British Journal of Cancer 97 659-669. (https://doi.org/10.1038/sj.bjc.6603906)

Vanneste M, Hanoux V, Bouakka M \& Bonnamy PJ 2017 Hyaluronate synthase- 2 overexpression alters estrogen dependence and induces histone deacetylase inhibitor-like effects on ER-driven genes in
MCF7 breast tumor cells. Molecular and Cellular Endocrinology $\mathbf{4 4 4}$ 48-58. (https://doi.org/10.1016/j.mce.2017.01.046)

Verhelst K, Verstrepen L, Carpentier I \& Beyaert R 2013 ІкB kinase $\varepsilon$ (IKKe): a therapeutic target in inflammation and cancer. Biochemical Pharmacology 85 873-880. (https://doi.org/10.1016/j.bcp.2013.01.007)

Vihinen T, Määttä A, Jaakkola P, Auvinen P \& Jalkanen M 1996 Functional characterization of mouse syndecan-1 promoter. Journal of Biological Chemistry 271 12532-12541. (https://doi.org/10.1074/ jbc.271.21.12532)

Weitsman GE, Li L, Skliris GP, Davie JR, Ung K, Niu Y, Curtis-Snell L, Tomes L, Watson PH \& Murphy LC 2006 Estrogen receptor-alpha phosphorylated at Ser118 is present at the promoters of estrogenregulated genes and is not altered due to HER-2 overexpression. Cancer Research 66 10162-10170. (https://doi.org/10.1158/00085472.CAN-05-4111)

Welboren WJ, Sweep FC, Span PN \& Stunnenberg HG 2009 Genomic actions of estrogen receptor alpha: what are the targets and how are they regulated? Endocrine-Related Cancer 16 1073-1089. (https://doi. org/10.1677/ERC-09-0086)

Wen Y, Yang S, Liu R, Perez E, Yi KD, Koulen P \& Simpkins JW 2004 Estrogen attenuates nuclear factor $\mathrm{kB}$ activation induced by transient cerebral ischemia. Brain Research 1008 147-154. (https://doi. org/10.1016/j.brainres.2004.02.019)

Yu S, Kim T, Yoo KH \& Kang K 2017 The T47D cell line is an ideal experimental model to elucidate the progesterone-specific effects of a luminal A subtype of breast cancer. Biochemical and Biophysical Research Communications 486 752-758. (https://doi.org/10.1016/j. bbrc.2017.03.114)

Received in final form 28 March 2019

Accepted 11 April 2019

Accepted Preprint published online 11 April 2019 (c) 2019 Society for Endocrinology Published by Bioscientifica Ltd. Printed in Great Britain 